\author{
N. Lachashvili, N. Eradze \& L. Khetsuriani
}

\title{
Floristic composition of pistachio-woodland (Pistacieta atlantici) of Georgia (South Caucasus)
}

\begin{abstract}
Lachashvili, N., Eradze, N. \& Khetsuriani, L.: Floristic composition of pistachio-woodland (Pistacieta atlantici) of Georgia (South Caucasus). - Fl. Medit. 30: 39-53. 2020. - ISSN: 1120-4052 printed, 2240-4538 online.

The floristic composition of pistachio-woodland (Pistacieta atlantici) of Georgia (South Caucasus) is studied. 250 species of vascular plants, which belong to 174 genera and 50 families, were recorded. Floristic structure, composition of chorotypes and life forms are commented. Based on the systematic structure of this flora and composition of chorotypes, 3 the main directions of florogenetic connections are identified: 1. South-West Asia, 2. Mediterranean, 3. Eurasian steppe. Attenuated form shows the impact of Iran-Turan deserts and connections to Europe. It was found that the formation of pistachio-woodland of Georgia was implemented in the bosom of Ancient Mediterranean with close contact with the boreal flora. Connection with savannas is not observed.
\end{abstract}

Key words: vegetation, vascular flora, chorotype, florogenetic connection, life forms.

\section{Introduction}

General distribution area of Pistacia atlantica Desf. comprises Mediterranean, SouthWest Asia, Caucasus and Crimea. In Caucasus area of $P$. atlantica is characterized by disjunction area. In particular, it main area covers Iori and Sheki uplands and Bozdahgi foothills. P. atlantica also is distributed on Mtkvari-Arax lowland, South Armenia and western part of North Caucasus. Altitudinal range of $P$. atlantica is from sea level to middle mountain belt. Pistachio-woodland (Pistacieta atlantici) is one of characteristic formations of semiarid regions of South Caucasus. Here its main area comprises south-estern part of Iori plateu. A little spreads on Mtkvari-Arax lowland and in South Armenia (Ivanova 1950; Prilipko 1970; Gulisashvili \& al. 1975; Ketskhoveli 1980; Khachidze 1985; Lachashvili \& al. 2007; Lachashvili \& Khachidze 2009). As well as the Pistacia atlantica distribution range, area of pistachio formation in the South Caucasus in the past was much more.

Pistacieta atlantici with other formations of xerophytic woodlands (arid open woodland, arid forest) are considered to be vegetation of the Tertiary period (Takhtajian 1946; Ivanova 1950; Agakhaniants 1981; Khachidze 1985). There is no consensus about its 
origin and florogenetic connections. Some researchers identify it with savanna, or to indicate their savanna origin (Sosnovsky 1943; Gulisashvili \& al. 1975; Gulisashvili 1980). And some researchers (Grossheim 1948; Rubtsov 1956; Ketskhoveli 1960, 1980; Khachidze 1985; Nakhutsrishvili 2013) consider pistachio forests in the independent type of vegetation "arid open woodland" (xerophytic open woodland). Kvachakidze (2001) uses term "arid forests". However, it should be mentioned, that none of the view are backed up by an analysis of the structure of pistachio-woodland communities. In most cases, the conclusions are built on the visual side pistachio communities, plant phenelogy and the general data. Part of the researchers (Kamelin 1989) pistachio-woodlands (Pistacieta verae, Pistacieta atlantici) with other formations of deciduous arid forests combines with special vegetation types, which they call East Mediterranean deciduous xerophilous forests, arid open woodlands and shrubberies. Some researchers of Caucasus forests, for example Dolukhanov (2010), hesitated to include pistachiowoodland in savanna before solving the problem and noted that with their structure, development and genesis pistachio-woodlands are original.

In the scientific literature data about the structure pistachio-woodlands of Georgia, and generally of South Caucasus, are scarce. The emphas is mostly on the typological composition. In rare cases their short geobotanical characterization is given (Khachidze 1985; Lachashvili \& Khachidze 2009; Dolukhanov 2010). The floristic composition and its analysis are not presented.

The aim of our research was determining the floristic composition of Pistacia atlantica formation.

Based on analysis of systematic structure, compositions of chorotypes and life forms reveal their florogenetic connections.

\section{Materials and methods}

The floristic and phytocenological data were obtained by the route method for long time (1995-2015).

Chorotypes and their general areas correspond to the methods and principles of Ivanishvili (1973), Portenier (2000a, 2000b) and Gagnidze (2004). Phytogeographic zoning of Earth by Takhtadjan (1978) is taken into consideration. During the selection of chorotypes detailing was emphasized. Mono, double, triple, and in some occasions fourfold regional chorotypes are selected. The names of all those main botanic-geographic units, that the chorotype area contains, are used in the names of chorotypes. During determination of chorotype of the species and subspecies, the main attention is directed to the center of gravity of the species (subspecies) spread. In case the plant is ranked as subspecies (subsp.), the chorotype of the subspecies is given. By mentioned methodology, in the most chorotypes (where there a need and an opportunity were) lower-ranking units chorological groups are separated. The selected chorotypes are apportioned in four major groups. They are: (1) boreal, (2) Ancient Mediterranean, (3) "connective" and (4) widespread. Such attitude gave the opportunity to conduct more detailed analyzes.

According to Takhtajan (1978) the boarders of the Ancient Mediterranean and Boreal regions are determined. 
Endemics of Caucasus are separated within borders of Caucasus ecoregion (Solomon \& al. 2013).

The main approach to the separation of phytocenological units (Pistacieta, Junipereta) is based on the dominant species, like it was used to be in the former USSR. Suffix "-eta", added on the genus name of dominant taxa, denotes "formation", which is the highest vegetation units (Shennikov 1964; Rabotnov 1983; Nakhutsrishvili 2013).

Life forms spectrum compiled according to classification systems of Raunkiaer (1934) and Serebriakov (1964).

The soil related terms are given according to Urushadze $(1999,2016)$.

\section{Description of study area}

In Georgia general area of Pistacia atlantica formation comprises southern-eastern part of Iori plateau, where well preserved in Vashlovani protected areas. A little intervenes in the northern and the northern-western parts of adjacent Eldari lowland (Fig. 1).

Altitudinal range of Pistacia atlantica formation in the southern-eastern parts of Iori plateau and the northern-western parts of Eldari lowland is between 250-600 m amsl. Communities of Pistacieta atlantici are distributed on the hills, plains and the lower part of monoclinal low ranges, also on the debris cones of dry gorges.

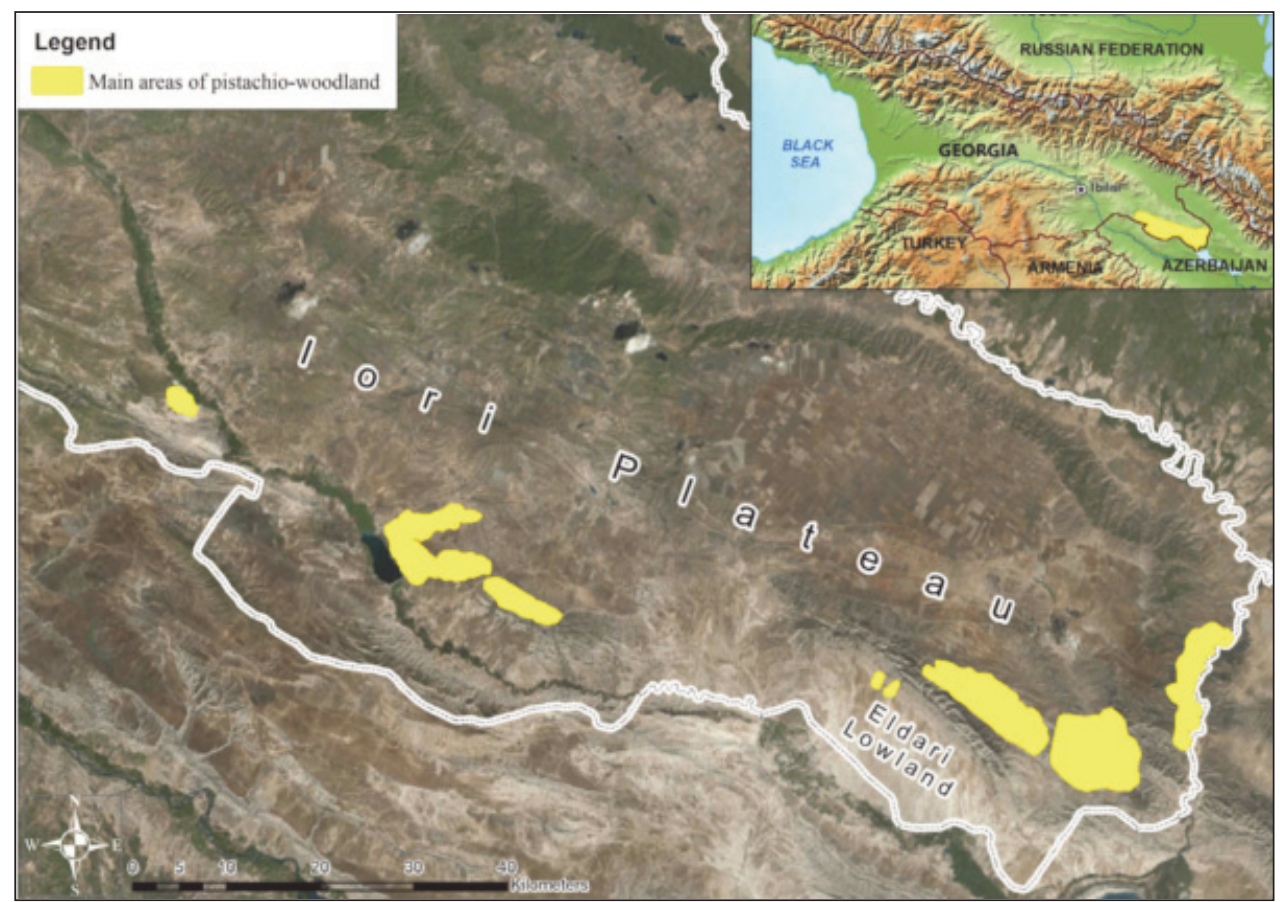

Fig. 1. Main area of Pistacia atlantica formation in Georgia. 
In the southern-eastern part of Iori plateau, Pistacia atlantica formation with Juniper formation (Junipereta; Juniperus foetidissima, J. polycarpos) form zonal type vegetation, which occupy an intermediate location between the desert and steppe vegetations (Lachashvili \& Khachidze 2009).

The southern-eastern part of Iori plateau belongs to semiarid regions. It is characterized by dry subtropical climate with relatively cold winter and long hot summer. Average annual temperature is $13^{\circ} \mathrm{C}$. Total annual precipitation fluctuates within $350-400 \mathrm{~mm}$. Evaporability is $900-1000 \mathrm{~mm}$, precipitation-evaporation ratio-0.4-0.6. The northern and the northern-western parts of Eldari lowland are within 250-300 m amsl and characterized by dry subtropical climate of semidesert. Average annual temperature is $14.2^{\circ} \mathrm{C}$. Average total annual precipitation is 200 (250)-350 mm. Evaporability is $1000-1200 \mathrm{~mm}$, precipitation-evaporation ratio - 0.3-0.5 (Kordzakhia 1961; Dzotsenidze 1964; Khachidze 1985).

The study area is not located none of meteostation. Nearest meteostation was away from main area of pistachio-woodland on average 12-20 km. Now meteostation does not function. Below is given klimadiagram built according to the data (Loladze 1967, 1970) of mentioned weather station (Fig. 2).

On the studied area pistachio communities mainly are developed on different modifications of grey-cinnamonic soils. Not infrequently soils are skeletal. Distribution of Pistacia

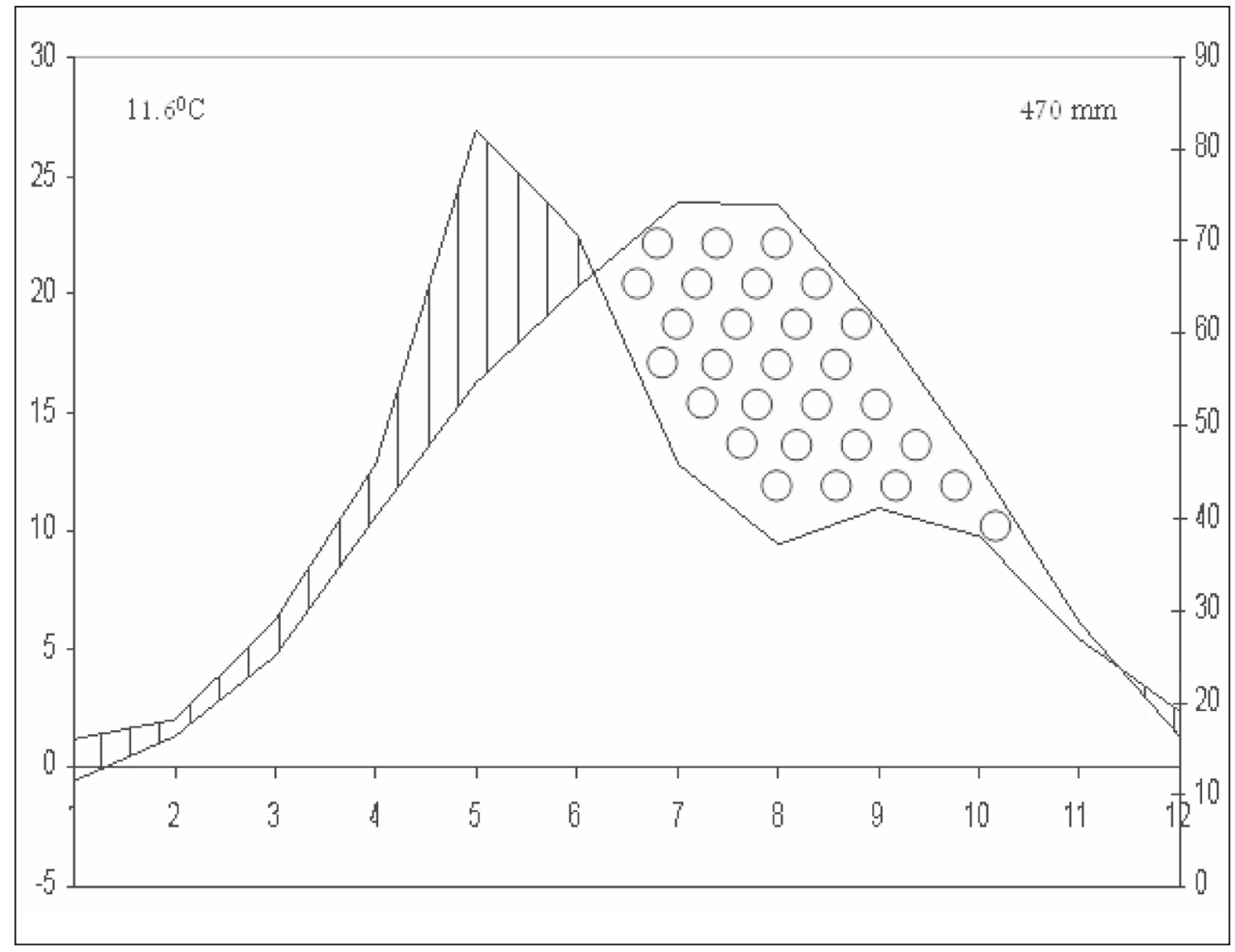

Fig. 2. Climograph of nearest meteo station from the study area 
atlantica communities on Eldari lowland associated with debris cones of dry gorges, which covered with shingles and soil is salinized slightly.

\section{Results}

Systematic structure of flora - 250 species of vascular plants, belong to 176 genera and 50 families, recorded in Pistacia atlantica formation of Georgia (Table 1).

Table 1. General spectrum of vascular flora of Georgia Pistacia atlantica formation

\begin{tabular}{|l|c|c|c|c|c|c|}
\hline \multirow{2}{*}{ Large Taxa } & \multicolumn{2}{|c|}{ Families } & \multicolumn{2}{c|}{ Genera } & \multicolumn{2}{c|}{ Species } \\
\cline { 2 - 7 } & Number & $\%$ & Number & $\%$ & Number & $\%$ \\
\hline Pteridophyta & - & - & - & - & - & - \\
\hline Gymnospermae & 2 & 4 & 2 & 1.1 & 4 & 1.6 \\
\hline Angyospermae & 48 & 96 & 172 & 98.9 & 246 & 98.4 \\
\hline among these: & & & & & & \\
\hline Dicotyledonae & 40 & 80 & 139 & 79.9 & 196 & 78.4 \\
\hline Monocotyledonae & 8 & 16 & 33 & 19 & 50 & 20 \\
\hline Total & 50 & 100 & 174 & 100 & 250 & 100 \\
\hline
\end{tabular}

Number of genera is disproportionately distributed by families. Most families are represented by 1-2 genera: 10 families - by two genera each, 25 families - by one genus. That is, out of 50 families, 35 comprising only $25.6 \%$ of the total number of genera ( 45 genera). Spectrum of 1-10 leading families by number of genera are given in table form (Table 2). Except Amaranthaceae, by 4 genera also Ranunculaceae is represented.

Table 2. Number of genera by 1-10 leading families in vascular flora of Georgia Pistacia atlantica formation.

\begin{tabular}{|c|c|c|}
\hline Family & Number of Genera & $\%$ \\
\hline 1. Asteraceae & 23 & 13.2 \\
\hline 2. Poaceae & 22 & 12.6 \\
\hline 3. Fabaceae & 13 & 7.5 \\
\hline 4. Brassicaceae & 11 & 6.3 \\
\hline 5. Caryophyllaceae & 11 & 6.3 \\
\hline 6. Lamiaceae & 10 & 5.8 \\
\hline 7. Rosaceae & 7 & 4.0 \\
\hline 8. Apiaceae & 7 & 4.0 \\
\hline 9. Rubiaceae & 5 & 2.9 \\
\hline 10. Amaranthaceae & 4 & 2.3 \\
\hline Total & 113 & 64.9 \\
\hline
\end{tabular}

The same families dominate by content number of species, though more or less different sequence is observed (Table 3 ). 
Table 3. Number of species by 1-10 leading families in vascular flora of Georgia Pistacia atlantica formation.

\begin{tabular}{|c|c|c|}
\hline Family & Number of species & $\%$ \\
\hline 1. Poaceae & 35 & 14.0 \\
\hline 2. Asteraceae & 31 & 12.4 \\
\hline 3. Fabaceae & 30 & 12.0 \\
\hline 4. Brassicaceae & 16 & 6.4 \\
\hline 5. Caryophyllaceae & 14 & 5.6 \\
\hline 6. Lamiaceae & 13 & 5.2 \\
\hline 7. Rosaceae & 8 & 3.2 \\
\hline 8. Rubiaceae & 7 & 2,8 \\
\hline 9. Amaranthaceae & 7 & 2.8 \\
\hline 10. Apiaceae & 7 & 2.8 \\
\hline Total & 168 & 67,2 \\
\hline
\end{tabular}

Share of $1-5$ leading families accounts $50.4 \%$ ( 126 species) of the total number of species. Asparagaceae and Papaveraceae are represented by 5 species each, and 3 families (Liliaceae, Plantaginaceae, Ranunculaceae) by 4 species each. 8 families comprise 3 species each, 9 families 2 species each and 18 families are represented by one species. As we can see, most of the families (27 families) are represented by 1-2 species and comprise only $14.4 \%$ of the total number of species.

Distribution of species by genera is represented in table form (Table 4).

Table 4. Number of Species in genera of the vascular flora of Georgia Pistacia atlantica formation.

\begin{tabular}{|c|c|c|c|}
\hline Genus & Number of Species & Genus & Number of Species \\
\hline Astragalus & 7 & Galium & 3 \\
\hline Stipa & 6 & Juniperus & 3 \\
\hline Medicago & 5 & Linum & 3 \\
\hline Aegilops & 4 & Papaver & 3 \\
\hline Bromus & 4 & Sedum & 3 \\
\hline Onobrychis & 4 & Silene & 3 \\
\hline Salsola & 4 & Veronica & 3 \\
\hline Alyssum & 4 & Vicia & 3 \\
\hline Allium & 3 & \multicolumn{2}{|c|}{ In the rest: } \\
\hline Artemisia & 3 & 24 genera & $2-2$ \\
\hline Gagea & 3 & 131 genera & $1-1$ \\
\hline
\end{tabular}

Composition of chorotypes (Geographical Range Types) - In order to determine the origin and florogenetic connections of vegetation, along with the study of systematic structure of flora, necessary to determination the composition of chorotypes. The study of chorotypes showed the following: 250 species of vascular plants recorded by us are grouped into 30 geographical range types. Their quantitative and percentage proportions are presented below by table form (Table 5). 
Table 5. Proportion of chorotypes in the vascular flora of Georgia Pistacia atlantica formation.

\begin{tabular}{|c|c|c|c|c|}
\hline Chorotype & $\begin{array}{l}\text { Number of } \\
\text { Species }\end{array}$ & $\%$ & $\begin{array}{c}\text { Number of } \\
\text { Species }\end{array}$ & $\%$ \\
\hline \multicolumn{5}{|c|}{ Boreal species } \\
\hline Caucasian & 28 & 11.2 & \multirow{4}{*}{39} & \multirow{4}{*}{15.6} \\
\hline Caucasian-Eurasian steppe & 9 & 3.6 & & \\
\hline Caucasian-Euxinian & 1 & 0.4 & & \\
\hline Euxinian & 1 & 0.4 & & \\
\hline \multicolumn{5}{|c|}{ Ancient Mediterranean Species } \\
\hline Ancient Mediterranean & 3 & 1.2 & \multirow{10}{*}{80} & \multirow{10}{*}{32} \\
\hline Mediterranean & 7 & 2.8 & & \\
\hline Southwest Asian & 8 & 3.2 & & \\
\hline Southwest Asian-Turanian & 8 & 3.2 & & \\
\hline Southwest Asian-Turanian-Central Asian & 4 & 1.6 & & \\
\hline Turanian & 1 & 0.4 & & \\
\hline Mediterranean-Southwest Asian & 37 & 14.8 & & \\
\hline Mediterranean-Southwest Asian-Turanian & 9 & 3.6 & & \\
\hline $\begin{array}{l}\text { Mediterranean-Southwest Asian-Turanian-Central } \\
\text { Asian }\end{array}$ & 2 & 0.8 & & \\
\hline Caspian & 1 & 0.4 & & \\
\hline \multicolumn{5}{|c|}{ "Binding Species" } \\
\hline Caucasian-Turanian & 3 & 1.2 & \multirow{12}{*}{90} & \multirow{12}{*}{36} \\
\hline Caucasian-Southwest Asian & 26 & 10.4 & & \\
\hline Caucasian-Southwest Asian-Central Asian & 1 & 0.4 & & \\
\hline European-Mediterranean-Southwest Asian & 15 & 6 & & \\
\hline European-Caucasian-Southwest Asian & 1 & 0.4 & & \\
\hline European-Ancient Mediterranean & 6 & 2.4 & & \\
\hline European-Mediterranean & 9 & 3.6 & & \\
\hline Southwest Asian-Caucasian-Eurasian steppe & 6 & 2.4 & & \\
\hline Mediterranean-Southwest Asian-Eurasian steppe & 18 & 7.2 & & \\
\hline Mediterranean-Eurasian steppe & 2 & 0.8 & & \\
\hline Euxino-Hyrcanian & 1 & 0.4 & & \\
\hline Caucasian-Hyrcanian & 1 & 0.4 & & \\
\hline Pontian-Irano-Turanian & 1 & 0.4 & & \\
\hline \multicolumn{5}{|c|}{ Widespread Species } \\
\hline Palaearctic & 36 & 14.4 & 36 & 14.4 \\
\hline Holarctic & 4 & 1.6 & 4 & 1.6 \\
\hline Cosmopolitan & 1 & 0.4 & 1 & 0.4 \\
\hline \multicolumn{5}{|c|}{ Total } \\
\hline & 250 & 100 & 250 & 100 \\
\hline
\end{tabular}

Composition of life forms - Spectrum of life form (Raunkiaer 1934) has the following form: therophytes - 120 species (48\%), hemicryptophytes (with biennial plants) $71(28.4 \%)$, phanerophytes - 24 (9.6\%), geophytes - $23(9.2 \%)$, chamaephytes - 12 (4.8\%). According to Serebryakov (1964) classification of life forms spectrum is as follows: annual plants - 120 species (48\%), biennial plants -7 (2.8\%), perenial herbaceous plants - $87(34.8 \%)$, semi-shrubs and draft semi-shrubs - $13(5.2 \%)$, shrubs $-18(7.2 \%)$, trees $-5(2 \%)$. 


\section{Discussion}

Systematic structure of flora - Basis of vascular flora is angiosperms. Dicotyledonous plants are 3,6 times more than monocotyledonous.

The data (Tables 2,3) is clear that the genera and species disproportionally distributed by families which is characteristic of vegetation developed in the extreme conditions. However, in comparison with adjacent to the desert vegetation, in which share of 1-10 leading families is $76.5 \%$ of total number of species (Lachashvili \& al. 2007; Lachashvili \& Khachidze 2010), the one-sidedness is reduced.

Low species diversity of genera is expressed sharply (Table 4). 131 genera (75.3\%) are represented only by one species and 24 genera $(13.8 \%)$ by two species each. That is, there are $89.1 \%$ of genera are represented by $1-2$ species. Thus, abundance of species in the floristic composition is due to relatively high number of genera.

The spectrum of first 10 (15) leading families by species composition gain great significance in the floristic study of the region as well as vegetation. Spectrum of first 10 leading families by content of species does not fit a standard frame of any important floristic centre (Mediterranean, Southwest Asia, Iran-Turan, etc), although the influence of various floristic centers is evident.

As in typical Mediterranean floras (Tolmachev 1986; Quezel 1978), the family of Fabaceae, Caryophyllaceae and Brassicaceae has high position with Poaceae and Asteraceae in the spectrum of flora of pistachio-woodland of Georgia. The same families dominate in almost every floras of Ancient Mediterranean. High share of family Lamiaceae (6 position in the spectrum) underlines connection with Ancient Mediterranean (especially Southwest and Midle Asian). Presence of another Ancient Mediterranean family - Apiaceae (Gagnidze 2000) in the top ten strengthens these ties. Both these families have leading positions in the floras of different regions of Ancient Mediterranean (Turril 1929; Kamelin \& al. 1989; Asaadi 2009; Dehshiri \& Jozipoor 2014; Baliousis 2016; Kargar Chigani \& al. 2017).

Quite high position of family Rosaceae in the spectrum, which is marked the leading positions in the nemoral, Submediterranean and boreal floras, is noteworthy. This family in the Mediterranean floras relatively rarely is included in the top ten and his position is not defined. In forest regions of Ancient Mediterranean (for example, Southwest Asia), this family is in top 10 (Heydari \& al. 2013; Aghaei \& al. 2013; Mataji \& al. 2013; Ghollasimood \& al. 2014; Roshan \& Heydari 2014; Azizi \& Keshavarzi 2016). Position of Rosaceae in the Irano-Turanian floristic spectra decreases from floras of forest region to the non-forest (Tolmachev 1986; Lachashvili \& al. 2007). Thus, one can say, that high position of Rosaceae in the florictic spectrum of pistachio-woodlands of Georgia should be considered as related signs of forest ecosystems.

Being in the top ten one of knot of Sahara-Gobi deserts family Chenopodiaceae (Amaranthaceae) is important, as a result of Irano-Turanian deserts influence. It is notable, that this family has the same position in floristic spectrum of pistachio-woodlands of Saharan Atlas - influence of Sahara deserts (Benaradj \& al. 2015a).

Family Liliaceae should be separately mentioned. With the modern sense it is presented by 4 species. But if reviewed according to the old wider (s. 1.) volume (including families: Asparagaceae - 5 species, Amaryllidaceae - 3, Colchicaceae - 1, Xanthorrhoeaceae - 1), 
then with 14 species it would take the 5-6 position in the spectrum. 5-6 position of this family is logical and also indicates on the Mediterranean and Southwest Asian impact.

Therefore, systematic structure of pistachio-woodlands of Georgia indicates on the Ancient Mediterranean character of flora. Boreal links are also identified.

It should be marked, that in diffrent areas (for example, South Caucasus, Middle Asia and Saharan Atlas) in the floristic spectra of pistachio-woodlands ecosystems are mainly same families dominate (Malysheva 1989; Aleksanyan 2011a; Benaradj \& al. 2015a). In spite of different positions of some families (for example: Rubiaceae, Chenopodiaceae and Rosaceae), the similarities between spectra are vivid.

Chorotypes - Large quantities of local - Caucasian and Caucasian-Southwest Asian species in the spectrum of chorotypes deserve special attantion. Area of most plants of Caucasian-Southwest Asian chorotype does not include all Southwest Asia and mainly limited with neighboring territory of South Caucasus. Broad participation of these chorotypes, in our opinion, indicates to forming of pistachio-woodland in semiarid regions of East Georgia and its outstanding Southwest Asia occurred in relationship with each other.

Southwest Asian species are represented by small quantity - totaly 8 species. Southwest Asian connections, mainly, are expreced by partisipation of different double, triple and quadruple regional chorotypes. The total share of these species is $50.8 \%$ (127 species).

Weak connection with the direction of Turan are vivid too. The total quantity of Turan related species is $21(8.4 \%)$. Their partisipation points to relativaly weak maintained connactions with Iran-Turan deserts.

Participation of Mediterranean chorotype plans is small - 7 species. Influence of the Mediterranean floristic centre and ties with it is expressed by participation of species of double, triple and quadruple regional chorotypes. Their total number is 92 species $(36.8 \%)$. Distribution range of one parts of these species are confined by East Mediterranean.

In terms of Mediterranean and Southwest Asian connections one should especially point to large spectrum of Mediterranean-Southwest Asian (-Turan-Central Asian) species [48 (19.2\%)].

The connection between Georgia pistachio-woodlands and Eurasian steppe is expresed in different chorotypes (Caucasian-Eurasian steppe, Southwest Asian-Caucasian-Eurasian steppe, Mediterranean-Southwest Asian-Eurasian steppe and Mediterranean-Eurasian steppe chorotypes). Ratio of the united species in these chorotypes is $14 \%$ (35 species).

Conections towards Europe are weaker (European-Mediterranean-Southwest Asian, European-Mediterranean, European-Ancient Mediterranean and European-CaucasianSouthwest Asian species). The total ratio of these spieces is $12.4 \%$ (31 species).

In the floristic composition important role also belongs to the Palaearctic species (14.4\%). Three groups excreted among them: Palearctic - 16 species, South Palearctic 12 and West Palearctic -8 .

Other chorotypes are represented by small number of species and does not play determinant role in shaping of floras structure. They with their participation enrich floristic composition. It should be noted that in the floristic composition of Georgia pistachiowoodland are not recorded tropical species.

By analyzing chorotypes it is obvious that in forming of Georgia pistachio-woodland Ancient Mediterranean species plays main role, which total share is almost 1/3 (32\%). Comparison with them participation of Boreal species are small - 15.6\% (39 species). And 
the largest number represented so-called "binding" species (90 species $-36 \%)$, which wide spectrum highlights the connections of different directions. High share of "binding" species are fully logical because study area located at the crossroads of the borders of various floristic centres. Such ration of chorotypes indicates that of Georgia Pistacieta atlanti$c i$ formation proceeded in the bosom of Ancient Mediterranean with close contact with the boreal flora. Connection with boreal floras in the first place are reflected by large participation local (Caucasian) and related with Eurasian steppe species. Here we shall remark, that part of researchers Caucasian chorotype are considering within Ancient Mediterraneanin (in particular in Submediterranean) region (Gagnidze 2004; Gagnidze \& Davitadze 2000; Shetekauri \& Gagnidze 2000). There are observed relatively weak ties to the European direction. Large participation of Palearctic species evidences on the connection with Europe and general with Palearctic, that support the boreal links. It is very important that in the modern floristic composition of pistachio-woodlands of Georgia connection with the tropics does not loom.

Floristic analysis of dry deciduous woodlands spread in the southern part of South Caucasus (South Armenia) revealed that also their formation is occurred in the bosom of Ancient Mediterranean with to the influence of boreal floras (Aleksanyan 2011b). The difference is that in South Armenia there is dominance of Ancient Mediterranean species. On their background participation of "binding" and boreal species is significantly reduced. Such changes indicate that the northward boreal connections increases, which is natural and logical. The Ancient Mediterranean origin of pistachio-woodland is also determined by the chorological analysis of Saharan Atlas. The influence of Mediterranean and Saharan-Sindian floristical centres is vivid (Benaradj \& al. 2015a).

Endemics - Among Caucasian species, 21 are endemic of Caucasus. 12 species of them are endemics of South Caucasus. Area of most endemic species mainly includes arid and semiarid regions of Caucasus. Area of 7 species which are united in the Caucasian chorotype goes slightly beyond the range of this chorotype and is charactarised by iradiation area. In particular:

Caucasian with East Anatolian irradiation - 2 species (Cotoneaster meyeri, Onobrychis radiata);

Caucasian with North-East and East Anatolian irradiation - 2 species (Astragalus brachycarpus, A. stevenianus);

Caucasian with Anatolian irradiation - 2 species (Erysimum leptophyllum, Scutellaria orientalis);

Caucasian with Pontian irradiation - 1 species (Scorzonera biebersteinii);

These species can be regarded as Caucasian subendemics.

Apart from species of Caucasian chorotype, Salsola nodulosa - plant of CaucasianTuran chorotype is endemic of Caucasus. Total number of Caucasian endemics is 22 species $(8.8 \%)$. Their share with subendemics is $11.6 \%$. To take in consideration that the research territory is located in the crossing area of the various floristic centres, this indicator should not be unsignificant.

Life forms - From the life forms spectrum it is clear that with largest number are represented those plants which unfavorable period tolerate (survives) in the form of seeds -120 species (48\%). By comparison with them number of species which buds has in the air are significantly smaller. Their total number is $36(14.4 \%)$. Between them middle position 
occupy species which the buds has to the level of the ground - 69 species $(27.6 \%)$. With smaller number are represented those species, which unfavorable periods tolerate with specialized underground bodies - $23(9.2 \%)$.

Outlined dominance of therophytes over hemicryptophytes is important aspect in herbaceuos plants' ratio. High ratio of therophytes emphasizes on Mediterranean character. Also, the spectrum has heteregeneous character; different signs of plats adaptation to enviromental conditions are vivid. In our view, such ratio of life forms is in compliance with the physical-geographic conditions (especially with climate and soil conditions) of study area.

The dominance of herbaceous plants is clearly highlighted in the spectrum of life form -214 species $(85.6 \%)$. Woody plants are represented by 23 species $(9.2 \%)$ and semiwoody plant by 13 species $(5,2 \%)$. One should remark, that dominance of herbaceous plants (especially of therophytes) in pistachio-woodlands and in general, in deciduous arid open woodland ecosystems is observed in different areas (Malysheva 1989; Alexsanyan 2011c; Benaradj \& al. 2015b).

By analyzing of the life forms' spectrum, we can say that in comparison with the typical forest share of woody plants is significantly reduced. On their background the number of the herbaceous (especially of therophytes) and semi-woody plants increased. Proportion of herbaceous (therophytes, hemicryptophytes and geophytes), semi-woody and woody plants, obviously, indicates on the transitional character between grassland and forest vegetations. From our point of view, spectrum of life forms has Ancient Mediterranean character.

The ratio of life forms by chorotypes is interesting.

In the composition of phanerophytes dominance of Caucasian-Southwest Asian, Mediterranean-Southwest Asian and Mediterranean chorotypes identified. European links observed also.

In the composition of semishrubs and dwarf semishrubs, despite small number of species, chorotypes are diverse and dominance any chorotype is not observed. The most pronounced connections with Southwest Asia, Turan and Mediterranean. Participation of local (Caucasian and Caucasian-Turanian) species is important. In the mentioned life form diversity of chorotypes is conditioned by in the pistachio-woodlands communities participates chamaephytes which are characteristic for various ecotopes.

In the composition of hemicryptophytes florogenetic links with Eurasian steppe are most pronounced. Ties with Irano-Turan deserts are reduced to minimal. EuropeanMediterranean influence is also outlined. Participate of local and Caucasian-Southwest Asian species is not insignificant.

In the composition of geophytes Caucasian-Southwest Asian and Caucasian species are dominated. Connections with Eurasian steppe observed also. Among them Irano-Turanian species are in very small quantity.

In the composition of therophytes dominance of Mediterranean-Southwest Asian chorotype are identified. The role of those species, which distribution range is advanced, on the one hand, to Europe and, on the other hand, to east (Turan, Midle Asia, Central Asia) is also important. Most of these species are ephemers and their bioecological features and phenology are in line with of the researched region's climat. They perform important role in the formation of ephemeral synusia of Irano-Turan deserts and at the same time they relate to the characteristic species of South Caucasus (among them of Georgia) desert vegetation. 
Thus, we can say that florogenetic connections with Southwest Asia and Mediterranean loom by almost all life forms and the links with Eurasian steppe mainly are reflected in the compositon of hemicryptophytes. Although, that the connections with Iran-Turan deserts reduced, in nearly all life forms (especially in therophytes) there are species that indicates on these links. The weak connections which are with Europe mostly revealed in the compositions of therophytes, hemicryptophytes and also phanerophytes (shrubs).

\section{General Conclusions}

Based on the analysis of systematic structure and chorotypes of floristic composition of Georgia pistachio-woodlands we can conclude that there are three the main directions florogenetic connections: (1) Southwest Asia, (2) Mediterranean and (3) Eurasian steppe. Floristic composition is enriched by local (Caucasian) species. In attenuated form are pronounced influence of Iran-Turan deserts, on the one hand and links to Europe on the other hand. It was found that the formation of pistachio-woodland of Georgia implemented in the bosom of Ancient Mediterranean in close contact with the boreal flora. Florogenetic connection with savannas is not observed.

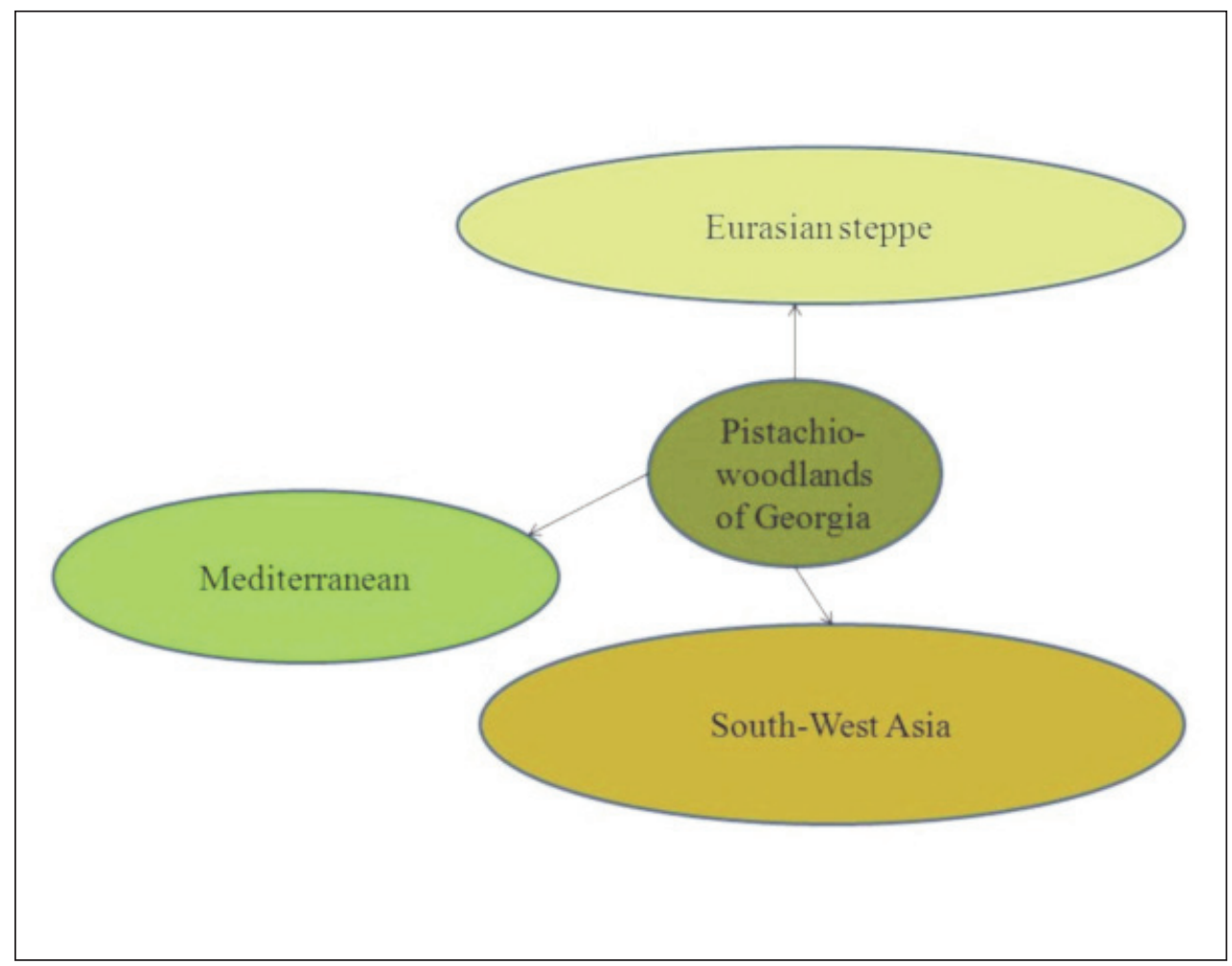

Fig. 3. Main directions of florogenetic connections of Georgia Pistacia atlantica formation. 
The individual components of floristic composition (systematic structure, composition of chorotypes, life form spectrum) clearly indicates on the transitional character of floras - for these are characteristic relevant characteristics as of forests, so of hemixerophilous shrubberies and of steppe. At the same time, none of the sign explicit dominance does not reaches. The obtained results confirm the notion of examination Pistacieta atlantici in independent vegetation type which is called arid open woodlands (in synonims: xerophytic forests, xerophytic woodlands).

Given the fact that pistachio-woodlanlands of Iori and Sheki plateaus are a single origin this conclusion can generalize for pistachio-forests of eastern part South Caucasus.

Floristic composition indicating life forms (Raunkiaer 1934; Serebriakov 1964) and chorotypes for each species in table form are given in the Elcetronic supplementary file (ESF1).

\section{Acknowledgements}

We are especially grateful to Dr. Merab Khachidze for conveying his data and for useful advice. We thank Mr. Konstantine Kereselidze and Mr. Nikoloz Kvaliashvili for mapping.

\section{References}

Agakhanyants, O. E. 1981: Aridnye gory SSSR. - Moscva [in Russian].

Aghaei, R., Alvaninejad, S., Zolfaghari, R. \& Gharehlar, M. R. M. 2013: Flora, Life Form and Geographical Distribution of Plants in West South Forests of Iran (Case Study: Vezg, Yasouj). - Int. J. Farm. Allied Sci. 2(23): 1046-1053.

Aleksanyan, A. S. 2011a: Sistematicheskaia struktura flory aridnych redkolesii Iujhnoi Armenii. Takhtajania 1: 163-168 [in Russian].

Aleksanyan, A. S. 2011b: Chorologicheski analiz flory aridnych redkolesii Iujhnoi Armenii. - Biol. J. Armenia 63(4): 83-91 [in Russian].

Aleksanyan, A. S. 2011c: Biomorfologicheskaia struktura flory aridnych redkolesii Iujhnoi Armenii. - Biol. J. Armenia 63(2): 31-36 [in Russian].

Asaadi, A. M. 2009: Floristic study of Firozeh watershed (North Khorasan Province). -Res. J. Biol. Sci. 4(10): 1092-1103.

Azizi, H. \& Keshavarzi, M. 2016: Floristic study of the Dupaza Mountain, Sardasht County, West Azarbaijan Province, NW Iran. - Phytol. Balcanica 22(1): 79-84.

Baliousis, E. 2016: Flora and vegetation of Mt Aphrodisio (Peloponnisos, Grerce). - Fl. Medit. 26: 31-61. https://doi.org/10.7320/flmedit26.031

Benaradj, A., Bouazza, M. \& Boucherit, H. 2015a: Phytodiversity the group to Pistacia atlantica Desf. in the Saharan Atlas (Bechar - Algeria). - Energy Proc. 74: 258-264. https://doi.org/10.1016/j.egypro.2015.07.593

_, — \& - 2015b: Ecologie du groupement a Pistacia atlantica dans l'atlas saharien oranais (Bechar - Algŭrie). - Fl. Medit. 25: 87-94. https://doi.org/10.7320/flmedit25.087

Dehshiri, M. M. \& Jozipoor, M. 2014 Angiosperms, Kuhdasht gypsum areas, Lorestan, Iran. - Check List 10(3): 516-523. https://doi.org/10.15560/10.3.516

Dolukhanov, A. G. 2010: Lesnaia Rastitel'nost' Gruzii. - Tbilisi [in Russian].

Dzotsenidze, G. S. (ed.) 1964: Atlass Gruzinskoi SSR. - Tbilisi-Moskva [in Russian].

Gagnidze, R. 2000: Diversity of Georgia's flora. Pp. 21-32 in: Beruchashvili, N., Kushlin, A. \& Zazanashvili, N. (eds), Biological and landscape diversity of Georgia. - Tbilisi. 
- 2004: Up to date problems and tasks of botanical geography of the Caucasus. - Not. Syst. Geogr. Inst. Bot. Thbilissiensis 44-45: 8-52 [in Russian].

— \& Davitadze, M. 2000: Adgilobrivi flora. - Batumi [in Georgian].

Ghollasimood, S., Amousi, O. \& Fattahi, B. 2014: Floristic composition, life forms and geographical distribution of semi steppe pastures of Western Zagros (case study: Perdanan, West Azerbaijan, Iran). - J. Biodiv. Environ. Sci. 4(4): 75-86.

Grossheim, A. A. 1948: Rastitel'nyi pokrov Kavkaza. - Moskva [in Russian].

Gulisashvili, V. Z. 1980: Savanna woodlands. - Tbilisi [in Russian].

—, Makhatadze, L. B. \& Prilipko, L. I. 1975: Rastitel'nost' Kavkaza. - Moskva [in Russian].

Heydari, M., Poorbabaei, H., Hatami K., Salehi, A. \& Begim Faghir, M. 2013: Floristic study of Dalab woodlands, north-east of Ilam province, west Iran. - Iranian J. Sci. Technol. 37A3: 301308.

Ivanishvili, M. A. 1973: Flora formatsii kolucheastragalovykh tragakantnikov severnogo sklona Bol'shogo Kavkaza. - Tbilisi [in Russian].

Ivanova, A. 1950: O listvennykh kserofil'nykh redkoles'iakh Armenii. Pp. 94-172 in: Trudi Botanicheskogo Instituta Akademii Nauk Armianskoi SSR, 8. - Erevan [in Russian].

Kamelin, R. V. 1989: Zakluchenie. Pp. 222-228 in: Kamelin, R. V. \& Rodin, L. E. (eds), Fistashniki Badkhyza. - Leningrad [in Russian].

—, Bochantsev, V. P. \& Gorelova, T. G. 1989: Kratki ocherk flory Badkhyza. Sosudistye rastenia. Pp. 7-21 in: Kamelin, R. V. \& Rodin, L. E. (eds), Fistashniki Badkhyza. - Leningrad [in Russian].

Kargar Chigani, H., Akbar Javadi, S., Zahedi Amiri, G., Jafari, M. \& Jamaleddin Khajeddin, S. 2017: The floristic composition and biological spectrum of vegetation in the Meymeh region of Northern Isfahan province, Iran. - Appl. Ecol. Environ. Res. 15(1): 415-428. https://doi.org/10.15666/aeer/1501_415428

Ketskhoveli, N. N. 1960: Sakartvelos mcenareuli saphari. - Tbilisi [in Georgian].

- 1980: Kserofitnye (aridnye) redkoles'ia. Pp. 273-276 in: Gribova, S. A., Isachenko, T. I. \& Lavrenko, E. M. (eds), Pastitel'nost' Evropeiskoi chasti SSSR. - Leningrad [in Russian].

Khachidze, M. 1985: Rastitel'nyi pokrov Shirakskogo ploskogor'ia i El'darskoi nizmennosti (Vostochnaia Gruzia), PhD. - Tbilisi.

Kordzakhia, M. O. 1961: Sakartvelos hava. - Tbilisi [in Georgian].

Kvachakidze, R. 2001: Forests of Georgia. - Tbilisi [in Georgian].

Lachahsvili, J., Lachashvili, N., \& Khachidze, M. 2007: Conspectus of flora of Kiziki (East Georgia). - Tbilisi.

Lachashvili, N. \& Khachidze, M. N. 2009: Typology and distribution pattern of vegetation of Kiziki (East Georgia, South Caucasus). - Caucasian Geographical Review 10: 90-96 [in Russian].

— \& - 2010: Desert flora and vegetation of Georgia. - Tbilisi [in Georgian].

Loladze, G. M. (ed.) 1967: Spravochnik po klimatu SSSR 14 - Gruzinskaya SSR, 2 - Temperatura vozdukha i pochvy. - Leningrad [in Russian].

- (ed.) 1970: Spravochnik po klimatu SSSR 14 - Gruzinskaia SSR, 4 - Vlazhnost' vozdukha, atmosfernye osadki, snezhnyi pokrov. - Leningrad [in Russian].

Malysheva, G. S. 1989: Fitotsenozy fistashnikov Badkhyza. Pp. 137-154 in: Kamelin, R. V. \& Rodin L. E. (eds), Fistashniki Badkhyza. - Leningrad [in Russian].

Mataji, A., Kia-Daliri, H., Babaie, S., Jafari, S. \& Roshan, S. A. 2013: Flora diversity in burned forest areas in Dehdez, Iran. - Folia Forest. Polonica, Series A, 55(1): 33-41. https://doi.org/10.2478/ffp-2013-0005

Nakhutsrishvili, G. 2013: The vegetation of Georgia (South Caucasus). - Geobotany Studies. Berlin. 
Portenier, N. N. 2000a: Methodical aspects of the elaboration of geographical elements in Caucasian flora. - Bot. J. 85(6): 76-84 [in Russian].

- 2000b: A system of geographical elements of the Caucasian flora. - Bot. J. 85(9): 26-33 [in Russian].

Prilipko, L. I. 1970: Rastitel'nyi pokrov Azerbaijana. - Baku [in Russian].

Quezel, P. 1978: Analysis of the flora of the Mediterranean and Saharan Africa. - Ann. Missouri Bot. Gard. 65(2): 479-534.

Rabotnov, T. A. 1983: Fitotsenologia. - Moskva [in Russian].

Raunkiaer, C. 1934: The life form of plants and statistical plant geography. - Oxford.

Roshan, S. A. \& Heydari, M. 2014: Short Communication: Flora, life form and chorological study of Quercus brantii habitat in Emamzadeh Abdullah woodland, Iran. - Biodiversitas 15(2): 245-250. https://doi.org/10.13057/biodiv/d150219

Rubtsov, N. I. 1956: Kserofitnye redkoles'ia, nagornye kserofity i subtropicheskie stepi. Pp. 573-594 in: Lavrenko, E. M. \& Sochava, V. V. (eds), Rastitel'nyi pokrov SSSR, poiasnitel'nyi tekst k "Geobotanicheskoi karte SSSR", 2. - Moskva-Leningrad [in Russian].

Serebriakov, I. G. 1964: Life forms of higher plants and their investigation. Pp. 146-205 in: Lavrenko, E. M. \& Korchagin, A. A. (eds), Field Geobotany, 3. - Moscva-Leningrad [in Russian].

Shennikov, A. P. 1964: VVedenie v geobotaniky. - Leningrad [in Russian].

Shetekauri, Sh. \& Gagnidze, R. 2000: Diversity of high-mountain endemic flora of the Greater Caucasus. Pp. 151-158 in: Beruchashvili, N., Kushlin, A. \& Zazanashvili, N. (eds), Biological and landscape diversity of Georgia. - Tbilisi.

Solomon, J., Shulkina, T. \& Schatz, G. E. (eds) 2013: Red list of the endemic plants of the Caucasus: Armenia, Azerbaijan, Georgia, Iran, Russia and Turkey. Monographs in systematic botany from the Missouri Botanical Garden (MSB) 125. - Saint Louis.

Sosnovsky, D. I. 1943: Opyt chronologizatsii ocnovnykh fitotsenozov Vostochnoi Gruzii. - Bull. Acad. Sci. Georgian SSR 4(2): 161-168 [in Russian].

Takhtajan, A. L. 1946: On the history of the development of vegetation of Armenia. Pp. 51-107 in: Trudy Botanicheskogo Instituta Akademii Nauk Armianskoi SSR, 4. - Erevan [in Russian].

- 1978: The Floristic regions of the World. - Leningrad [in Russian].

Tolmachev, A. I. 1986: Metody sravnitelnoi floristiki i problemy florogeneza. - Novosibirsk [in Russian]

Turrill, W. B. 1929: The plant life of the Balkan Peninsula. Oxford.

Urushadze, T. (ed.) 1999: Soil Map of Georgia. - Tbilisi.

- 2016: Soils of Georgia. - Tbilisi.

Adresses of the autors:

Nikoloz Lachashvili ${ }^{1 *}$, Nino Eradze ${ }^{2} \&$ Liana Khetsuriani ${ }^{3}$,

${ }^{1}$ Ilia State University, Institute of Botany; National Botanical Garden of Georgia. 1, Botanikuri Str., Tbilisi, 0114, Georgia. E-mail adress: lachashvili@gmail.com, nikoloz.lachashvili@iliauni.edu.ge

${ }^{2}$ Georgian National Botanical Garden. 1, Botanikuri Str., Tbilisi, 0114, Georgia. Email adress: ninia.eredze@gmail.com

${ }^{3}$ Ilia State University, Institute of Botany. 1, Botanikuri Str., Tbilisi, 0114, Georgia. E-mail adress: liana.khetsuriani@iliauni.edu.ge

*Corresponding autor. 
